DOI: https://doi.org/10.31392/NPU-nc.series9.2020.20.04

UDC: 81 '384

Ganna V. Izyumtseva

National Pedagogical Dragomanov University, Kyiv, Ukraine

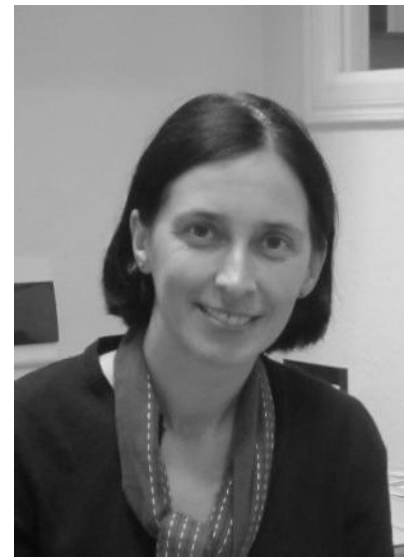

\title{
METHODOLOGY FOR ANALYSIS OF THE PENTATEUCH METAPHORICS (ENGLISH BIBLE)
}

\section{Bibliographic Description:}

Izyumtseva, G. V. (2020). Methodology for Analysis of the Pentateuch Metaphorics (English Bible). Scientific Journal of National Pedagogical Dragomanov University. Series 9. Current Trends in Language Development, 20. 47-63. https://doi.org/10.31392/NPU-nc.series9.2020.20.04

\section{Abstract}

The article considers the critical problem of methodology for the study of metaphorical senses in Biblical texts. It substantiates the importance of going beyond the structural and semantic formation of the Pentateuch texts to involve in the analysis of their metaphorics additional metaphorical senses refracted through the prism of doxic presupposition and present in the reflective reality of the recipients.

The vectors of the Pentateuch metaphorics analysis are identified, namely: 1) author's doxa (based on the Pentateuch texts); 2) doxic presupposition of recipients (based on the questionnaire). The verbal and mental dimensions of metaphorics (metaphorical picture of the world, metaphorical concepts, conceptual metaphors) are identified; they determine the methodology of the research.

Described complex methodology of metaphorics analysis includes: 1) the technique of semantic and cognitive metaphorical modeling aimed at reconstruction of the metaphorical picture of the world (the first stage); 2) the technique of the metaphorical concepts analysis (the second stage); 3) the questionnaire technique (the third stage); 4) the technique of semantic and cognitive reconstruction of conceptual metaphors from the standpoint of doxic presupposition (the fourth stage).

Arguments in support of selected methods and methodological techniques are offered; the stages of analysis of the metaphorical concept CHARACTER are demonstrated; its structure is established; it was revealed that the core of Biblical metaphorical concept CHARACTER is formed by the feature 'mercy' (56\%) that absolutely dominates over other conceptual features; therefore, it is the main trait of human character in the perspective of individual author-specific worldview.

It was found that the introduced methodology is effective for the Pentateuch metaphorics investigation.

Keywords: semantic and cognitive modelling, technique of reconstruction, metaphor, doxic presupposition, metaphorical concept, conceptual metaphor. 


\section{Introduction.}

Recent linguistic studies testify that the world of ideas never finds its complete expression through the language form; therefore, it is critical to conduct interdisciplinary research, to unify the attempts of researchers working in different fields, and to use complex methods of investigation. This approach allows scholars to embrace maximum of aspects and levels of considered linguistic facts, to identify and fully characterize their horizontal and vertical semantic connections, to penetrate into the depth of structures that arise on the "border" of language and reasoning, and without comprehension of which the knowledge about the world and the man remains shallow and fragmentary.

There has been ongoing linguistic investigation in the domain of sacred. Such respectable issues as "Metaphor and God-talk" (1999), "The Bible through Metaphor and Translation" (2003), Lieven Boeve, Kurt Freyaerts (Ed.); "Job 28: Cognition in Context" (Biblical Interpretation Series) (2003), E. Van Wolde (Ed.); "Cognitive Linguistic Explorations in Biblical Studies" (2014), Howe Bonnie, B. Joel (Ed.); "Religion, Language, and the Human Mind" (2017), Paul Chilton and Monika Kopytowska (Ed.), and others bring together their results.

It is worth pointing out the considerable studies of the conceptual aspect of sacred language (T. P. Vilchinska 2010, 2011, 2013, 2014; P. V. Matskiv 2006, 2014, 2016; M. V. Skab 2008, 2009, 2015, 2018; A. Barcelona 1999; Alec Basson 2006; Olaf Jakel 1999; Pholip King 2012; Lam 2012; Terrance R. Wardlaw 2008, 2010; Ellen van Wolde 2006, 2008, 2009, 2013; Kotze Zacharias, 2004) and the study of metaphors (R. Bischops 2018; Mary Th. DesCamp 2005, 2014; H. Van Hecke 2019; Kuczok Marcin 2018; A. Somov 2014; P. M. Shitikov 2013; N. Stienstra 1993; J. Steen 1997; Eve E. Sweetser 2014).

V. V. Alpatov, M. M. Boldyrev (2008), A. V. Korolyova, O. O. Cherkhava (2017) use cognitive-matrix analysis to access different cognitive contexts for the analysis of religious texts. Based on the theory of Ronald Langacker, Ellen van Wolde developed the method of a cognitive relational approach (Reframing Biblical Studies: When Language and Text Meet Culture, Cognition and Context, 2009). It allows analysis of cognitive structures emerging as a result of interaction of Biblical words, texts and historical complexes in the light of massive concrete as well as metaphysical social and cultural contexts.

Importantly, despite a decades-long tradition of divergent research in this field and, despite constant investigation of metaphor in different discourses, the metaphor of fideistic discourse in general and the metaphorics of the Pentateuch in particular has been subjected to comprehensive semantic and cognitive analysis neither in Ukrainian nor in foreign linguistics. In our opinion, this indicates the methodology problem - the lack of methods for studying the language of sacred texts. Therefore, the development of a comprehensive approach to the study of the Pentateuch as a text of fideistic nature is timely and relevant.

\section{Aim and Objectives.}

The aim of the article is to describe and substantiate the comprehensive methodology for the Pentateuch metaphorics analysis (English Bible, the Orthodox Study Bible).

\section{Objectives:}

- to describe the methodological foundation of the study;

- to outline those important provisions on the metaphor which form a pivot in representation of vectors of research on the metaphorics of the Pentateuch texts;

- to identify the stages of the research;

- to offer arguments in support of the methods introduced for each stage;

- to make a step-by-step description of the metaphorics methodology. 


\section{Methodology.}

The research objectives determine the methodological vector and methodological basis of the study. Consequently, the theoretical and methodological foundation underpinning the study allows the development of a comprehensive methodology for the Pentateuch metaphorics research: the concept of doxical presupposition (developed in the works of A. A. Zernetska); semantic and cognitive approach to the study of language phenomena (M. M. Boldyrev, Y. V. Kravtsova, O. S. Kubryakova, L. O. Kudryavtseva, Z. D. Popova, J. A. Sternin, A. Wierzbicka, and others); the theory of conceptual metaphor introduced by G. Lakoff and M. Johnson and supplemented by critical remarks from A. M. Baranov, A. P. Chudinov, S. Coulson, J. Foconnier, J. Grady, Yu. M. Karaulov, Z. Kovecses, E. McCormack, J. Steen, M. Turner, J. Zinken, and others); theory of embodied cognition (J. M. Johnson, G. Lakoff); theolinguistic concept (D. Crystal, O. Gadomsky, E. KucharskaDreiss, N. Mechkovska, J-P. Van Noppen, V. I. Postovalova); the theory of a concept as a linguistic and cultural phenomenon (M. F. Aleferenko, V. I. Karasyk, G. G. Slyshkin, S. G. Vorkachev), the concept of gestalt in a linguistic perspective (N. F. Aleferenko, M. M. Boldyrev). In general, the study is conducted in line with the holistic principle of knowledge representation, which, according to O. O. Selivanova, "does not separate the linguistic from the extralingual, but combines sensory, motor information at one and the same conceptual level, where it appears within one format (Kossyn 1980; Jackendoff, 1984: 54)" (as cited in Selivanova, 2014: 391).

\section{Results.}

Contemporary linguistics puts the idea of language investigation in close connection with the fundamental aspects of human existence at the centre of its concern. Such tendency encourages us to go beyond the structural and semantic formation of texts, and study the metaphorics of the Pentateuch from the standpoint of doxic presupposition.

\subsection{The main vectors of the Pentateuch metaphorics research.}

The semantic content of the Pentateuch metaphors has been built over millennia in the historical and sociocultural context of life of both ancient Israel and the Universal Christian Church, in the context of the synthesis of science, politics, religion, art, and literature of the world. At the same time, in this perspective the interpretation of the formed layer of knowledge depends on the knowledge that society generates and instills in its members (Zernetskaya, 2014: 272), that is to say doxic knowledge ("doxa" - the point of view of the majority, belief). Doxic knowledge, more precisely doxic presupposition (from the Latin prae "in front" and supposition "assumption") is beliefs, views embedded in a person at a subconscious pre-reflective level. Under this approach, they are taken to be formed by the very social reality (Kachanov, 2000: 3). As such, these beliefs shape the process of comprehension and reflection of each person, and, consequently, model comprehension and reflection of both the authors and recipients of the texts. Therefore, the meanings embodied in the metaphors of the Pentateuch texts bear the imprint of doxa stemming from author's sub-consciousness, i.e. are refracted by the author's reflective activity, and are presented in the perspective of his (the author's) doxic presupposition. At the same time, the recipients, as those who have their own reflective reality, while interpreting the text metaphors contribute to the growth of metaphorical meanings stemming from their mind, i.e. formed within their own (recipients') system of doxic knowledge. That is why, the idea that the meanings of Biblical metaphor are formed on the basis of diachronic-synchronous interaction of different cognitive contexts refracted through the prism of both the author and recipients' doxic presuppositions seems to us reasonable and indispensable. Thus, going beyond the structural 
and semantic formation of texts leads to the involvement in the analysis of additional senses (presented from the standpoint of the doxic presupposition of recipients). It is these senses that, in our opinion, form one more sense dimension of the Biblical metaphor. Without the integration of this sense component, the understanding of the reality embodied in the metaphor of the Pentateuch will be impoverished and incomplete.

Proceeding from such considerations, we argue that the metaphorics of the Pentateuch should be studied both from the standpoint of the author's doxa which is represented directly by the texts of the Pentateuch, and the doxic presupposition of recipients. It is such reasoning that determines the main vectors of this study, namely: 1) the study of metaphors based on the texts of the Pentateuch; 2) going beyond the structural and semantic formation of texts and studying the Pentateuch metaphors on the basis of data gathered with the help of questionnaires. The outlined vectors of the research determine the vectors of our reasoning in search for optimal methods of semantic and cognitive study of metaphorics, and requires meticulous the semantic and cognitive approach-based consideration of the phenomenon of metaphorics.

\subsection{Metaphorics as a three-dimensional verbal and mental formation.}

The analysis of relevant publications allows us to consider metaphorics of the text to be a three-dimensional mental and verbal formation which integrates: 1) the metaphorical picture of the world; 2) metaphorical concepts; 3) conceptual metaphors. Let's dwell on given dimensions of metaphorics in more detail.

\subsubsection{The metaphorical picture of the world.}

The metaphorical picture of the world is the first dimension to consider. At the present stage, linguametaphorical research sees the metaphor as a phenomenon existing on two levels: linguistic and cognitive. Such two-level presence allows us to interpret and, at the same time, explore the metaphor as "an integrated verbal and mental construct created as a result of human mental and verbal activity" (Kravtsova, 2011: 47). Metaphorics verbalises the knowledge of the world that an individual (ethnic group) acquires as a result of prelingual (physical, sensory) and lingual experience, and express itself as a metaphorical picture of the world of a particular bearer of linguistic culture (or ethnicity). It (the metaphorical picture of the world) is the result of conceptualization and categorization of the unique subjective - personal worldview of the creative personality; the embodiment of a set of his image - associative ideas about the world; reflection of those components of the world that seem to an individual the most important and which, in his opinion, characterize the world in its entirety (Pocheptsov, 1990: 111).

The individual picture of the writer's world is realized in the artistic text. In his time, V. G. Admoni rightly pointed out that "the artistic text springs out the specific (egocentric) internal state of the artist as the mental - sensory - conceptual comprehension of the world in a form of language..." (Admoni, 1994: 120). According to V. P. Belyanin, the artistic text is realization of the individual picture of the world, constructed by creative imagination of the author and embodied by selected linguistic means (Belyanin, 2000: 55-56).

Consequently, it is through the metaphorical picture of the world that metaphorics creates a gateway to the figurative consciousness of the author. On the one hand, metaphorics manifests itself through the metaphorical picture of the world; on the other hand, it allows unveiling and recreating the author's unique worldview. In this view, it is the metaphorical picture of the world that emerges as one of the metaphorics dimensions which makes its analysis indispensible for comprehension of the Pentateuch metaphorics. 


\subsubsection{The metaphorical concept.}

So far we have argued that metaphorics manifests itself through the metaphoric picture of the world. Here we will add that, additionally, metaphorical nominations of the text (metaphorics) are the means of objectification of metaphorical concepts. These specific mental constructs constitute another dimension of metaphorics. Individual metaphorical concepts are most clearly manifested in the metaphorics of literary texts as "the result of creative rethinking of the national picture of the world on the basis of special individual author-specific associations of the writer" (Kravtsova, 2014: 102).

Note that, like the concept in general, a metaphorical concept (hereinafter MC) is a "quantum" of condensed emotionally experienced mode of being, a way and product of cognition of the world. At the same time, the $\mathrm{MC}$ is a figurative component of the corresponding ethnocultural concept, a kind of figurative-mental construct, the content of which is formed by all its linguistic (usual metaphors recorded in explanatory dictionaries and occasional metaphors found in the course of studying the texts, discourses) representants and associates - verbalised cognitive properties (their language realizations), which determine figurative analogue and associative connections of realities. The number of the MC representants (language metaphors) is not fixed. With the loss of a figurative element, the language metaphor turns into a direct nomination, and ceases to function as a representative of a corresponding $\mathrm{MC}$. The change of representatives leads to a change in the content of the MC and its structure which is being determined by the importance of cognitive features of metaphorical projection within the framework of corresponding ethnoculture.

The most important associations for the bearers constitute the nucleus and the area around the nucleus of the metaphorical concept; it is determined by the quantitative composition of the representatives of this concept. The periphery of the MC is formed by individually significant cognitive features. Shifts in the qualitative and quantitative composition of representatives and associates of the MC can manifest themselves through changing the hierarchy of meanings in a particular ethnoculture. Therefore, given the above, following $\mathrm{Yu}$. V. Kravtsova, we believe that the metaphorical concept is a complex figurative-mental formation, which includes units of verbal (usual and occasional metaphorical meanings) and nonverbal (associates) levels and which is structured in accordance with the hierarchy of meanings relevant to a particular ethnoculture (Kravtsova, 2013: 150-151).

Another point we find important for this investigation in this context is that within a single ethnic group any object can be transformed into an ethnocultural concept with a corresponding metaphorical concept as its component. The logic behind this argument is given below.

According to V. I. Karasyk, ethnocultural concept is a subtype of a cultural concept mental structure, relevant and essential for a particular ethnoculture as a whole (Karasik, 2000: 98). Refraining from the discussion of the terminological vagueness of the concepts "concept" and "cultural concept" in the context of linguocognitology and linguocultural science, the significant for our study opinion of scientists (S. G. Vorkachev, V. I. Karasyk, V.V. Kolesov, G. G. Slyshkin) that any concept is able to acquire a value-semantic dimension within a particular ethnic group should be underlined (Alefirenko, 2016: 199). According to V. V. Kolesov, any concept can function as a marker of ethnic language system (Kolesov 2004). Consequently, within the framework of a separate ethnic group, any concept can be considered as having potential to become the ethnocultural concept (as a subtype of a cultural concept) with the corresponding metaphorical concept as its figurative component.

Thus, the metaphorical concept is a complex figurative-mental formation, figurative cultural dominant existing as a component of the ethnoconcept. On the one hand, the 
metaphorical concept is objectified at the level of metaphor as a key notion. On the other hand, it, as a mental structure, reflects stable in the collective and individual consciousness figurative analogue and associative connections of realities, thus constructing a holistic image of a fragment of the world embodied in Biblical metaphors. In this perspective, the analysis of metaphorical concepts is necessary for comprehensive investigation of the metaphorics of the Pentateuch.

\subsubsection{The conceptual metaphor.}

Essential to our study is the view that each surface metaphor (metaphoric language / verbal expression) is the expression of an implicit cognitive / conceptual metaphor. The conceptual metaphor is found in conceptual depths of a linguistic metaphor. It implies that although the linguistic and conceptual metaphors can be analysed as separate phenomena, both of them are incarnations of the same image; therefore, they are inseparable. Under this perspective, the metaphorics of the Pentateuch can be considered to be the expression of implicitly present conceptual metaphors. In addition, it is worth re-emphasising that languagelverbal expressions are possible (available) only because human conceptual system is metaphorical by nature. Furthermore, it is concepts formed within the consciousness of a man, not meanings of words or objective categories that constitute the foundation of metaphor. So, they are conceptual, not linguistic, in nature (Lakoff 1993, Lakoff, Johnson 2003). Consequently, their study, as a necessary and important step for understanding Biblical metaphors, makes sense.

In the context of exploration of the Pentateuch metaphorics, noteworthy is that the essence of metaphor is the mechanism of understanding and experiencing one phenomenon in terms of another. Furthermore, in the process of metaphorization, the structures of knowledge come into action. Interaction of the cognitive structure of the "source" (source domain) and the cognitive structure of the "goal" (target domain) is observed. These cognitive structures should be viewed as mental spaces, conceptual domains. In addition, the structure that is abstract correlates with the sensory structure. Our immediate concern is that the cognitive structure itself based on the understanding of one conceptual domain in terms of another is considered to be a conceptual metaphor itself (Lakoff, Johnson 2003).

According to such interpretation, we believe that, since metaphysical (sacred) realities are abstract, metaphorization is one of the main cognitive mechanisms of their realization. The process of metaphorization allows structuring, and thus comprehending the sphere of metaphysical in terms of the sphere of practical, sensual. "It follows that abstract realities, and hence metaphysical (sacred) realities, are expressed through the prism of specific realities, and hence through a conceptual metaphor, which becomes a unique cognitive mechanism for modelling spiritual experience (both personal and collective), and at the same time, a means of cognition" (Izyumtseva 2020). Close to our point of view is the claim of N. Stientstra, who in the study "YAHWH is the Husband of His People" formulates it as follows, "metaphor and analogical language is the only possible way of expressing the divine" (Stienstra, 1993: 51).

It should be mentioned that the process of metaphorization, that is to say the "metaphorical projection" (metaphorical mapping) results in the conceptual area overlapping and, thus, in creating a kind of metaphorical concept (V. A. Maslova 2012; G. Lakoff, M. Turner 1989; A. Potts, E. Semino 2019; E. Semino, Z. Demjen, J. E. Demmen 2018; Steen 2011, 2013; E. Sweetser, M. Descamp 2014; P. H. Thibodeau, L. Boroditsky 2011), which leads to the blurring of the concepts of conceptual metaphor and metaphorical concept. However, these concepts should not be equated (Kravtsova, 2013: 150). 
From the standpoint of the semantic and cognitive approach, the metaphorical concept should be understood as a certain image-mental invariant, which is realised in a number of linguistic metaphorical variations, as a figurative component of the ethnoconcept; the result and at the same time a means of conceptualizing the world. For example, as the analysis of the metaphor of the Pentateuch showed, the language variants of the metaphorical concept CHARACTER are shows no partiality, does not take a bribe, faithful, keeps covenant, honest, mercy, merciful, longsuffering, abounding in truth, true, abounding in mercy, humble, righteous, upright, uprightness, compassionate, stubborn, forgiving, and clean. Metaphorical concepts reflect "essential for a given ethnocultural community figurative ideas formed on the basis of stable associations of native speakers, and determine the features of national figurative thinking" (Kravtsova, 2014: 95-96).

Unlike metaphorical concepts, conceptual metaphors or metaphorical models are stable correspondences between conceptual domains (source area and target area) that capture and preserve important concepts, ideas for a particular linguistic and cultural community (MORALITY IS PURITY, GOD IS PERSAN, PEOPLE ARE PLRE, etc.). Their essence is to understand the object. They are intertwined in a network of interconnected structures and serve as models for the construction of linguistic metaphors. Thus, "Metaphors as linguistic expressions become possible merely because there are metaphors in the conceptual system of man" (Lakoff 1993, Lakoff, Johnson 2003).

Metaphors are motivated by special structures of a non-propositional nature - "image schemes". Image-schemes are the essence of a conceptual metaphor and allow structuring our experience at the pre-conceptual level (before we consciously created the concept of something) (Lakoff, 1990: 64). For example, the image-scheme "top-bottom" is the basis of the orientation metaphor, which reflects the idea of the social structure of society and its spiritual priorities (STATUS IS UP / LAW STATUS IS DOWN; MORAL IS UP / IMMORAL IS DOWN). In fideistic discourse, this orientational metaphor gives God a special UP orientation (the highest status): Most High (Gn. 4:18, 21); the Lord Himself is God in heaven above... (Dt. 4:39). He also embodies the highest standard of morality: He is upright (Dt. 32:4). This conclusion is reconfirmed by a conceptual model (cultural model) THE GREAT CHAIN OF BEING "a hierarchical or holarchic concept, which means that each subsequent stage exceeds and at the same time embraces all previous ones" (Wilburn, 2000: 72), continuity of being (Aristotle, J. Herbert, E. Kant, G. Leibniz, Plotinus, B. Spinoza). It is used to organize the human world in the semantic plane of the Pentateuch. The very metaphor of the chain of beings was introduced by Macrobius, who at the beginning of the $5^{\text {th }}$ century provided a summary of Plotinus' concept in the form of a commentary to the work of Cicero (Lovejoy 1936, 2001: 66). In general, from both theological and materialist positions, the highest link in the chain is occupied by transcendent God. Based on the thoughts of F. Alexandria, A. Lovejoy, Leibniz, Plotinus, Spinoza, He is the most perfect, complete, unique, and from which flows, emanates, realizes the variety of being, according to K. Wilber, "from top to bottom: from the most perfect form of being. In modern linguistics, the conceptual metaphor THE GREAT CHAIN embraces rational knowledge about the nature of all things" (Lakoff \&Turner, 1989: 171-172). Due to this metaphor, the essence or thing of one hierarchical level can be expressed in terms of the essence or thing of another hierarchical level. Based on the conceptual model THE GREAT CHAIN OF BEING, the transcendental essences of the Pentateuch are understood in human terms (essences of the lower hierarchical level); this is fixed by the conceptual model GOD IS PERSON and reflected in the anthropomorphic language of the Scripture. The Pentateuch conceptualises YHWH as the highest authority. Due to this, not only a sphere of the sacred is 
structured, but also the world order, the temporal-spatial coordinates of humanity as a whole and of each person individually.

Consequently, all the above said about the conceptual metaphor as a dimension of metaphorics implies that the metaphorics of the Pentateuch can be considered to be the expression of implicitly present conceptual metaphors. Thus, their study is necessary and important for comprehension of Biblical metaphors in general and the metaphorics of the Pentateuch in particular.

\subsection{On the Pentateuch metaphorics research methodology.}

Given the considerations so far, it is reasonable to state that only in the unity of its sense dimensions the metaphorics of the Pentateuch emerges in its entirety. The metaphorical picture of the world, metaphorical concept, and conceptual metaphor interwining form a whole sense image, embody and, at the same time, interpret it. Therefore, in addition to the vectors of the research (outlined in Section 4.1.), the study of the metaphorics should include the analysis of: 1) the metaphorical picture of the author's world; 2) metaphorical concepts; 3) conceptual metaphors. This leads us to the research methodology that includes the following methods: 1) the method of semantic and cognitive analysis of metaphors (Yu. V. Kravtsova) to identify the special meanings of the author's individual metaphorical worldview by reconstructing the metaphorical picture of the author-specific world (the first stage); 2) the method of research of metaphorical concepts (Yu. V. Kravtsova) to establish figurative meanings relevant to the bearers of a particular ethnoculture (the second stage); 3) the method of questionnaires (the third stage); 4) the semantic and cognitive analysis (G. Lakoff, M. Johnson), which involves the reconstruction of conceptual metaphors from the standpoint of doxic presupposition (the fourth stage). Let us dwell on the outlined stages of the study and justify the reasonability of the selected methods.

\subsubsection{The first stage of the study.}

The metaphorics both at the general and individual language level is a manifestation of a complex discrete cognitive formation. Its analysis allows us to clarify the ethnoculturespecific figurative ideas about the world, and thus penetrate into the essence of mental structures (M. M. Boldyrev, Yu. V. Kravtsova, O. S. Kubryakova, L. O. Kudryavtseva, Z. D. Popova, J. A. Sternin, A. Wierzbicka et al.).

Thus, we start with the semantic and cognitive analysis which was developed by $\mathrm{Yu}$. V. Kravtsova. This method involves metaphorical modeling by means of the reconstruction of the metaphorical picture of the world with the subsequent use of the obtained data for identification and analysis of the metaphorical concepts. Semantic and cognitive analysis is realized in several stages: 1) analysis and systematization of the corpus of metaphorical contexts (study of the metaphorical contexts collected by a continuous sample, determination of connections and interdependencies); 2) the establishment of basic structures - metaphorical models as three-component structures (they include the original and new conceptual areas, and semantic and cognitive formant); 3) structuring the metaphorical models as components of megamodels (systematization of metaphorical models according to the direction of metaphorical projection) and organizing submodels (specification of metaphorical models); 4) summarizing the preliminary results of the study of metaphorical models (comparison of metaphorical models, determining the patterns of metaphorical modelling); 5) verification of the obtained data and their use to identify metaphorical concepts (Kravtsova, 2014: 56).

It is worth noting that semantic and cognitive analysis of metaphors also involves the use of additional methods, namely: 1) content analysis (for identifying metaphors in different 
texts, their quantification and qualitative-quantitative analysis of the collected metaphorical contexts); 2) contextual analysis (in order to clarify the semantic content of metaphors); 3) component analysis (to study the semantics of metaphorical nominations and determine the seme structure of metaphors); 4) metaphorical modelling (for identifying parameters and constructing metaphorical models); 5) conceptual analysis (to establish the content of metaphorical concepts) (Kravtsova 2014).

As shown by the semantic and cognitive analysis of the metaphor of the Books of the Pentateuch ("Genesis", "Exodus", "Leviticus", "Numbers" and "Deuteronomy"), individual author-specific picture of the world is elaborated within the megaspheres "Man", "Society", "Plant", "Inorganic World", and "Artifact". The most productive metaphorical modelling is observed within the megamodels with the megasphere-source "Man". In addition, within each megasphere, spheres and subspheres are established.

To demonstrate the metaphorical modelling within the semantic and cognitive method, the metaphorical model "Man $\rightarrow$ Transcendent Essence" is reconstructed in the process of the Pentateuch metaphorics analysis. The model represents the model of metaphorical thinking of the author of the Pentateuch in the context of the historical background of his time.

The megamodel "Man $\rightarrow$ Transcendent Essence" is realised in metaphorical models:

1) "physical properties of the man $\rightarrow$ God > the object manifestation" which is expressed in the following submodels: a) "parts of the human body $\rightarrow$ God $>$ discovery of an object": Your right hand, O God, dashed the enemy in pieces (Ex. 15: 6); Under His feet was, as it were, a paved work of sapphire stone (Ex. 24:10); Then I will take away My hand, and you shall see My back (Ex. 33:23); I will set My face against that soul (Lv. 17:10); the Lord lift up His countenance (Nm. 26: 6), etc.; b) submodel "physical actions $\rightarrow$ God > dynamics (action / movement)": God divided (Gn. 1: 7); God led (8: 2); He formed (Gn. 2: 7); God walking (Gn. 3: 8), and others; c) submodel "physical actions $\rightarrow$ God > process": the Lord your God will_purify (Dt. 30: 6); d) submodel "physical states $\rightarrow$ God > manifestation (presence / absence)": He rested (Gn. 2: 2); e) submodel "language / voice $\rightarrow$ God > manifestation of the object (realization)": they heard the voice of the Lord God (Gn. 2: 8); the Lord God called Adam and said to him (Gn. 2: 9); I heard Your voice (Gn. 3:10); the Angel of God called to Hagar out of heaven (Gn. 21: 17); etc. e) submodel "language / voice $\rightarrow$ God > sound": God said (Gn. 1: 3); (Gn. 1: 6); (Gn. 1: 9); (Gn. 1: 11); (Dt. 21: 12); (Ex. 6: 36); the Lord said (Gn. 18:13); (Ex. 11: 1); (Nm. 3:40); (Nm. 6:22); (Ex. 24:12); (Dt. 10:10); (Dt. 34: 4); etc.

2) "physiological properties of the man $\rightarrow$ God > the object manifestation": a) submodel "physiological processes $\rightarrow$ God >method of realization": God saw the light (Gn. 1: 4); looked upon the earth (Gn. 6:12); b) submodel "physiological processes $\rightarrow$ God > discovery of an object (reaction to something / someone)": the Lord smelled sweet aroma (Gn. 8:21); c) submodel "physiological processes $\rightarrow$ God > activity": God... breathed into his nostrils (Gn. 2: 7);

3) "mental properties of the man $\rightarrow$ God > discovery of an object": a) submodel "memory $\rightarrow$ God > recalling": God remembered (Gn. 8: 1); God remembered His covenant (Ex. 3: 20); etc. b) submodel "thinking / intellect $\rightarrow$ God > realization": God thought (Gn. 8: 21); God knows (Gn. 3: 5); I know (Gn. 22:12); c) submodel of "thinking / intellect $\rightarrow$ God > reaction to something / someone": He thought this over (Gn. 6: 6); etc.;

4) "spiritual properties of the man $\rightarrow$ God > evaluative": submodel "character traits $\rightarrow$ God > positive evaluation": He would keep the oath He swore to your fathers (Dt. 7: 8); keeps covenant and mercy (Dt. 7: 9); showing mercy (Dt. 5:10); a faithful God (Dt. 7: 9); etc. 
$5)$ "mental properties of the man $\rightarrow$ God > the object manifestation (presence / absence)": a) submodel "spiritual essence of the man $\rightarrow$ God > the disclosure of the object in relation to something / someone": My soul shall not abhor you (Lv . 26:11, 30); b) submodel "feeling $\rightarrow$ God > reaction to something / someone (different types)": They provoked Me to jealousy (Dt. 33: 21); jealous God (Ex. 20: 5); a jealous God, repaying the sins (Dt. 7: 8); c) submodel "feeling $\rightarrow$ God > revealing the object": the Lord loves (Dt. 7: 8); He hated them (Dt. 9: 28); d) submodel "emotions $\rightarrow$ God > reaction to something / someone (different types)": They moved Me to anger (Dt. 33: 21); God was grieved (Gn. 6: 6); the Lord rejoiced (Dt. 28: 63); etc. e) submodel "emotions $\rightarrow$ God > intensity (strengthening / weakening)": I also have walked in hostility (Lv. 26: 41); the Lord was very angry (Ex. 32: 10); the Lord was aroused in anger (Dt. 29: 26); the Lord... in anger, in wrath, and in great indignation (Dt. 29: 27); etc.

Thus, the semantic and cognitive analysis of the Pentateuch metaphorics allows modeling the unique author-specific worldview with forked structure of source and new spheres of metaphorization that reflects hierarchy of figurative senses within linguistic consciousness of the author. The model used for illustration of the metaphorical modeling technique reveals that the figurative worldview of the author of sacred texts is anthropocentric, determined by the productivity of the megasphere of metaphorization "Man". Thus, in the centre of the figurative world of the author of the Pentateuch is the man in his entirety - physical, physiological, spiritual, and social.

\subsubsection{The second stage of the study.}

At the next stage of the metaphorics investigation, we analyse the basic metaphorical concepts in order to establish the figurative senses they engrave, essential both for the author of the Pentateuch and the whole ethnocultural community. It is important to underline that in our analysis not all metaphorical concepts, but basic metaphorical concepts are of special interest; their main characteristics are: 1) dominance in metaphorical picture of the world; 2) invariance; 3) variability of linguistic (speech) representations; 4) the stability of associations (Kravtsova, 2014: 101).

As our pilot analysis has shown, one of the basic metaphorical concepts of the Pentateuch is the concept of CHARACTER. However, given the specifics of the materials under consideration, in the case of the CHARACTER concept, we are dealing not only with an ethnoconcept, but with a concept that encodes a matrix of cultural behavior of universal plan and goes beyond the figurative thinking of a particular individual or nation. In the narrow sense, the Pentateuch (Torah) was written by a Jew for the people of Israel. However, in a broad sense, the Pentateuch is an integral part of the Scripture. It is addressed to all nationalities without exception. In our opinion, today the very feeling of spiritual belonging to the "seed" of Abraham is the "core" around which the concept of ethnicity is formed in the context of sacred texts. The individual can identify himself as a descendant of the Patriarch, follow the Ten Commandments to belong to the universal family of Christians within which he feels not like "outsider" regardless of the nationality or borders. Therefore, although the author(s) of the Pentateuch may appear to be a Jew writing for Jewish people, the knowledge his writing contains forms new connections between people, thus expanding the concept of ethnicity in the context of the Bible message.

We will demonstrate the necessary steps for the analysis of metaphorical concepts using as an example the concept of CHARACTER (Kravtsova 2014). The first step of the analysis is to determine the national specifics of the metaphorical implementation of this concept based on the analysis of usual figurative meanings recorded in explanatory dictionaries (Note that the analysis of usual figurative meanings is problematic, as in 
American lexicography the designation of figurative meanings is not practiced, or in British dictionaries the fixation of figurative meanings is not regular) (DeCesaris \& Aslina, 2002: 79). For example, among all the representatives of the CHARACTER concept (shows no partiality, does not take a bribe, faithful, keeps covenant, honest, mercy, merciful, longsuffering, abounding in truth, true, abounding in mercy, humble, righteous, upright, uprightness, compassionate, stubborn, forgiving, clean), usual figurative meanings recorded in explanatory dictionaries are not found.

The second step is to identify individual and group features of the metaphorical implementation of this concept emerging as a result of the researcher's interpretation of occasional metaphorical meanings. For example, in the process of exploration of the concept CHARACTER the following occasional metaphorical meanings were discovered:

Clean. Characterised by the absence of malicious intent: I did this thing with a clean heart (Gn. 20: 5, 6).

Shows no partiality. Unchanging (not subject to outside influence): For the LORD your God... shows no partiality (Dt. 10: 17).

Does not take a bribe. The same as 'shows no partiality': For the LORD your God... nor takes a bribe (Dt. 10: 17).

Faithful. Showing consistency (in thoughts and feelings): the faithful God (Dt. 7: 9).

Keeps covenant. The same as 'faithful': God... who keeps covenant God (Dt.7: 9).

Honest. Accurate: You shall have honest scales, honest weights, an honest ephah, and an honest hin (Lev. 19: 36).

Mercy. The object manifestation (discovery of an object): Now when Moses went into the tabernacle of meeting to speak with Him, he heard the voice of One speaking to him from above the mercy seat $(\mathrm{Nm} 7: 8,9)$.

Merciful. Providing relief (positively perceived): showing mercy (Dt. 5:10); the LORD God, merciful (Ex. 34: 6-7); it will be that when he cries to Me, I will hear, for I am merciful (Ex. 22: 27); as You were merciful to them (Nm. 14: 19).

Abundant in mercy. Filled with compassion (shown especially to an offender or to one subject to one's power) (positively perceived): The LORD is ... abundant in mercy (Nm. 14: 18).

Compassionate. The same as 'merciful': The Lord God, compassionate (Ex. 34: 6);

True. The same as 'faithful': The Lord God, abounding in mercy and true (Ex. 34: 6); The Lord is abundant in ...truth (Nm. 14: 18).

Longsuffering. Characterised by long-term stability: the LORD God,... longsuffering (Ex. 34: 6); The LORD is longsuffering (Nm. 14: 18).

Forgiving. One who stops resentment (removes claims and puts an end to the feeling of resentment): the LORD God,... forgiving iniquity and transgression and sin (Ex. 34: 7).

Humble. Characterised by low activity: uncircumcised hearts are humbled (Lev. 26: 41).

Righteous. 1. Acts exclusively according to moral principles: The LORD is righteous (Ex. 9: 27); Righteous... is He (Dt. 31:4); 2. Positively perceived: And what great nation is there righteous judgments (Dt. 4: 8); righteous hands (Gn. 20: 5, 6).

Upright. Characterized by moral superiority: upright is He (Dt. 31: 4).

Uprightness. The same as 'upright': the uprightness of your heart (Dt. 9: 5);

Stubborn. Characterised by intensity (resistance to full force): made his heart stubborn (Dt. 2: 30).

The analysis has revealed that the most common metaphor is mercy (43 cases).

The third step is to establish cognitive features of metaphorical projection on the basis of component analysis of all representatives of the metaphorical concept under consideration 
as well as cognitive interpretation of semes, description of these features with the help of associates and their qualifiers (according to hyperonymo-hyponymic relations).

Cognitive level (associates) of the metaphorical concept CHARACTER:

1. The object manifestation:

1) intensity: 'shows permanence' (the faithful God); 'unchanging (not subject to outside influence)' (the LORD your God... shows no partiality); 'the highest' (made his heart stubborn);

2) activity: 'exclusively according to the standard' (The LORD is righteous); 'low activity': (hearts are humbled); 'termination of a process': (the LORD God,... forgiving iniquity and transgression and sin);

3 ) the discovery of an object: (a mercy seat);

3. Evaluation: 'positive assessment' (righteous judgments; righteous hands); (The LORD is ... abundant in mercy); 'pleasantly perceived' (clean heart); positively perceived (as You were merciful to them).

4. Time: duration: 'long-term stability' (the LORD God,... longsuffering).

3. Measure: the highest degree: 'accuracy' (honest scales);

The fourth step is to verify the established cognitive features by semantic and cognitive metaphorical modelling.

The obtained results of cognitive interpretation of semes are supported by the results of metaphorical modelling. All identified semantic-cognitive formants (semantic element which acts as a motivating property in a process of metaphorical projection of one denotativeconceptual sphere onto another one, and "reflects the systematic relationship of language and cognitive structures" (Kravtsova, 2011: 47)) in the productive metaphorical models (given below) are verbalised cognitive features which motivate metaphorization. They are formulated in the most general form and marked as qualifiers of associations:

1) "mental properties of the man $\rightarrow$ social relations: evaluation": submodel "character traits $\rightarrow$ speech communication > positive evaluation": And what great nation is there righteous judgments (Dt. 4: 8);

2) "human mental properties $\rightarrow$ human physical properties> evaluation": submodel "character traits $\rightarrow$ body parts > positive evaluation": righteous hands $(\mathrm{Gn} .20: 5,6)$;

3) "human mental properties $\rightarrow$ physiological properties of the man the object manifestation": submodel "character traits $\rightarrow$ human internal organs > activity (low)": uncircumcised hearts are humbled (Lev. 26: 41);

4) "human mental properties $\rightarrow$ physiological properties of the man > relational (position)": submodel "character traits $\rightarrow$ internal human organs > 'the highest vertical position' (moral superiority)": the uprightness of your heart (Dt. 9: 5);

5 ) "human mental properties $\rightarrow$ physiological properties of the man > the object manifestation": submodel "character traits $\rightarrow$ human internal organs > intensity (the highest)": made his heart stubborn (Dt. 2: 30);

6) "human mental properties $\rightarrow$ human physiological properties > evaluation": submodel "character traits $\rightarrow$ human internal organs > "positive evaluation"': clean heart (Gn. 20: 5, 6);

7) "mental properties of the man $\rightarrow$ God > the object manifestation": a) submodel "character traits $\rightarrow$ God > intensity 'constancy": the faithful God (Dt. 7: 9); God... who keeps covenant (Dt. 7: 9); He would keep the oath (Dt. 7: 8); keeps covenant and mercy (Dt. 7: 9); b) submodel "character traits $\rightarrow$ God > intensity 'unchanged' (not exposed to external influences)": the LORD your God... shows no partiality (Dt. 10:17); For the LORD your God... nor takes a bribe (Dt. 10: 17); c) submodel "character traits $\rightarrow$ God > activity "termination"': the LORD God, forgiving iniquity and transgression and sin (Ex. 34: 7); 
d) submodel "character traits $\rightarrow$ God > activity 'constant"": The LORD is righteous (Ex. 9: 27); Righteous... is He (Dt. 31: 4);

8 ) "mental qualities of the man $\rightarrow$ God > evaluative": submodel "character traits $\rightarrow$ God > positive evaluation": the LORD God, merciful (Ex. 34: 6-7); the LORD God, compassionate (Ex. 34: 6); 'The LORD is ... abundant in mercy (Nm. 14: 18); the LORD God, ... abounding in .. and true (Ex. 34: 6); showing mercy (Dt. 5: 10);

9) "mental properties of the man $\rightarrow$ God > time": submodel "character traits $\rightarrow$ God > longevity": the LORD God, ... longsuffering (Ex. 34: 6), (Nm. 14: 18);

10) "mental properties of man $\rightarrow$ technique > measure": a) submodel "traits $\rightarrow$ device > the highest degree of accuracy": You shall have honest scales, honest weights, an honest ephah, and an honest hin (Lev. 19: 36);

11) "mental properties of the man $\rightarrow$ building (room)> the object manifestation": submodel "character traits $\rightarrow$ interior items > discovery of an object": a mercy seat (Ex. 25:17).

The fifth step is to describe the content of the metaphorical concept on the semantic (usual-metaphorical and occasional-metaphorical sublevels) and cognitive (associativemetaphorical) levels.

As our analysis has shown, the content of the metaphorical concept CHARACTER is formed by the following representatives and associates:

1. Semantic level:

1) usual-metaphorical level: not revealed;

2) occasional metaphorical sub-level: shows no partiality, does not take a bribe, faithful, keeps covenant, honest, mercy, merciful, longsuffering, abounding in truth, true, abounding in mercy, humble, righteous, upright, uprightness, compassionate, stubborn, forgiving, clean.

2. Cognitive (associative-metaphorical) level: 'shows consistency'; 'unchanged (not subject to external influences)'; 'the highest intensity'; 'acts exclusively according to the standard'; 'low activity'; 'cessation of activity'; 'discovery of an object'; 'pleasantly / positively perceived'; duration: 'long-term stability'; 'accuracy' (the highest degree); 'the highest vertical position'.

The sixth step is to rank the identified cognitive traits (associates) by the degree of frequency and the nature of manifestation. Thus, the preliminary ranking of the identified cognitive traits (associates) revealed the following:

1) the nuclear zone: associates with the qualifiers "the object manifestation ('discovery of an object')" $-56 \%$;

2) the around-nuclear zone: associates with the qualifiers "evaluation: positive evaluation" - 17\%; "the object manifestation" - 'intensity' - 8\%, 'activity' - 7\%;

3 ) the peripheral zone: associates with qualifiers "measure" $-5 \%$ ('accuracy'); "relational: the highest vertical position" $-4 \%$; "time: long-term stability" $-3 \%$.

The seventh step is to describe the structure of the metaphorical concept - its nuclear, around-nuclear zone, and periphery.

The preliminary analysis has made evident that the structure of the metaphorical concept CHARACTER is organized as follows:

1) the nuclear zone includes associates with the qualifiers "the object manifestation ('discovery of an object')"; 2) the around-nuclear zone includes associates with the qualifiers: "evaluation: positive evaluation", "the object manifestation ('intensity'; 'activity')";

3) peripheral zone: associates with qualifiers "measure ('accuracy', 'the highest degree')"; "relational: highest vertical position", "time: 'long-term stability"”'. 
So, the carried out MC analysis demonstrated the capacity of the metaphorical concepts to model the reality as they incorporate relevant for ethnos knowledge, value characteristics, and experiences. To demonstrate the seven-step technique of research of metaphorical concepts, the metaphorical concept CHARACTER was used. It allowed discovering the peculiarity of figurative-associative mentality of ethnos as it is objectified in usual and occasional figurative meanings (verbal level), and fixed as cognitive features / associates (non-verbal level).

Thus understood, the demonstrated technique allows the $\mathrm{MC}$ analysis at verbal and non-verbal levels. The verbal level is nothing but the level of linguistic metaphors, that is to say metaphorics. Under this perspective, the metaphorics and the MC emerge as "two sides of the same coin". Consequently, the analysis of the one presupposes the analysis of another one; this perfectly serves the aim of our research.

\subsubsection{The third stage of the study.}

At the third stage of the research a questionnaire is conducted. The survey is done in order to obtain necessary information for semantic-cognitive reconstruction of the conceptual metaphors of the Pentateuch (from the standpoint of recipients' doxic presupposition) as well as making general conclusions.

\subsubsection{The fourth stage of the study.}

At the fourth stage of the study, drawing on the theory of conceptual metaphor and the theory of embodied cognition as methodologies of scientific research, we conduct semantic and cognitive reconstruction of the conceptual metaphors of the Pentateuch on the basis of material collected by using the method of questionnaires. It is done to obtain additional senses of the Biblical metaphors presented from the standpoint of the doxic presupposition of recipients.

The preliminary semantic and cognitive reconstruction of conceptual metaphors on the basis of a questionnaire has shown that recipients' comprehension of Biblical metaphors is realized by metaphorical expansion from the source sphere:1) three-dimensional space (verticality, centre-periphery, distance, objects, etc.); 2) the man (his physical, physiological, mental and spiritual properties); 3) interpersonal relationships (family relationships, social roles, etc.) on the sphere-goal of metaphysical reality. Thus, as preliminary examination allows us to suggest that the recipients' comprehension of the Pentateuch metaphorics is led and structured by such conceptual metaphors as:

Orientational conceptual metaphors: GOD'S STATUS IS UP, GOOD IS UP, CENTRAL IS IMPORTANT, SIN IS DOWN, HEAVENS IS UP, and other.

Ontological metaphors: GOD IS CREATOR, GOD IS HELPER, GOD IS FATHER, GOD IS KING, GOD IS HELPER, CLEANLINESS IS MORALITY, GOD IS OBJECT, WORD IS OBJECT, and other.

Structural conceptual metaphors: LEADING A MORAL LIFE IS MAKING A JOURNEY ON GOD'S WAY, LEARNING IS EATING and other.

However, the final conclusions can be made only after processing all data collected from the recipients. Overall, the preliminary results of the semantic and cognitive reconstruction of conceptual metaphors (from standpoint of doxic presupposition) support the significance of going beyond the structural and semantic formation of texts and the studying the Pentateuch metaphors on the basis of data gathered with the help of questionnaires. 


\section{Discussion.}

The suggested methodology shows the logic of our reasoning as far as the semantic and cognitive approach to the Pentateuch metaphorics research, and as it is determined by two vectors of investigation (substantiated in section 4.1.). Although at this stage of research is it too early to make conclusions regarding the metaphorics sense "scope", it may be regarded as certain that described methodology allows revealing the metaphorics senses in their verbal and mental integrity.

Importantly, that within the framework of examination of metaphorical conceptual sphere of Russian literature of the first part of the XX century (poetry and prose of Z. Hippius, A. Bielyi, and A. Akhmatova), among other basic metaphorical concepts, a metaphorical concept CHARACTER is found (Kravtsova 2014: 253). However, in terms of their content, the Russian literature metaphorical concept CHARACTER and the Biblical one are totally different. The core of the Biblical metaphorical concept CHARACTER is constituted by the only character trait 'mercy' (56\%). It absolutely dominates over other traits; therefore, it is the main feature of human character in the perspective of individual author-specific worldview of the Pentateuch. Unlike the Biblical concept, Russian literature metaphorical concept is mostly represented by metaphors 'mean', 'gentle', 'lazy', and 'timid'.

Interesting enough is that the analysis of the results of the pilot survey shows that, in general, the conceptual metaphors reconstructed from the standpoint of doxic presupposition (based on questionnaires) basically coincide with the conceptual metaphors reconstructed as a result of semantic-cognitive analysis of the metaphor based on the Pentateuch texts, namely: GOD IS CREATOR, GOD IS HELPER, GOD IS FATHER, GOD IS KING, LEADING A MORAL LIFE IS MAKING A JOURNEY ON GOD'S WAY, CLEANLINESS IS MORALITY, CENTRAL IS IMPORTANT, GOOD IS UP and others. However, as we have already stated, the final conclusions can be made only after gathering optimum information from the recipients, and conducting a complete semantic-cognitive analysis of metaphors.

Thus, at this stage, it is safe to say that the metaphorical picture of the world, the metaphorical concept, and the conceptual metaphor are sense-inseparable; therefore, consideration of one involves consideration of another. These constructions intertwine to form a whole image of senses. They embody and at the same time interpret metaphorics; thus, allowing us to penetrate into the depths of consciousness and grasp the essence of the author's intention. Which, given the specifics of the studied texts, is extremely interesting.

\section{Conclusions.}

In the article we have argued that the comprehensive study of the Pentateuch metaphorics requires the semantic and cognitive approach. Furthermore, we substantiated the need to go beyond the structural and semantic formation of the Pentateuch texts to involve in the analysis of their metaphors additional metaphorical meanings refracted through the prism of doxic presupposition and available in the reflective reality of recipients.

Under such perspective the vectors of the metaphorics research were characterized from the standpoint: 1) the author's doxa; 2) doxic presupposition of recipients.

Mental and verbal dimensions of metaphor (metaphorical picture of the world, metaphorical concepts; conceptual metaphors) were established, which determined the research methodology.

Described complex methodology of metaphorics analysis includes: 1) the technique of semantic and cognitive metaphorical modeling aimed at reconstruction of the metaphorical picture of the world (the first stage); 2) the technique of the metaphorical concepts analysis 
(the second stage); 3) the questionnaire technique (the third stage); 4) the technique of semantic and cognitive reconstruction of conceptual metaphors from the standpoint of doxic presupposition (the fourth stage). It is established that the proposed method implements the idea of a comprehensive study of the Pentateuch metaphorics.

\title{
A b breviations
}

\author{
Gn. - Genesis \\ Dt. - Deuteronomy \\ Ex. - Exodus \\ Lev. - Leviticus \\ $\mathrm{MC}$ - metaphorical concept \\ Nm. - Numbers
}

\section{References}

Admoni, V. G. (1994). Sistema form rechevogo vyskazyvaniya [The system of forms of speech utterances]. Nauka.

Alefirenko, N. F. (2016). Lingvokul'turologija: cennostno-smyslovoe prostranstvo jazyka: ucheb. posobie [Linguoculturology: value and sense space of language: manual]. 5-e izd., ster. FLINTA.

Belyanin, V. P. (2000). Osnovy psikholingvisticheskoy diagnostiki. Modeli mira v literature: monografiya [Basics of psycholinguistic diagnostics. World models in literature: monograph]. Trivola.

Cherkhava, O. O. (2017). Rekonstruktsiia teolinhvistychnoi matrytsi relihiino-populiarnoho dyskursu (na materiali anhliiskoi, nimetskoi ta ukrainskoi mov) [Reconstruction of Theolinguistic Matrix of Religious Popular Discourse (Based on the English, German and Ukrainian Languages)]: Thesis Abstract.

DeCesaris, J., \& Aslina, V. (2002). The Representation of Figurative Senses in Learners' Dictionaries. In Gottlieb, Henrik; Jens Erik Mogensen; Arne Zettersten (eds.), Symposium on Lexicography X. Proceedings of the Tenth International Symposium on Lexicography May 4-6, 2000 at the University of Copenhagen, Max Niemeyer, Tübingen.77-90. (Lexicographica).

Zernetskaya, A. A. (2014). Funktsional'naya sistema verbal'no-kommunikativnoy deyatel'nosti (kompetentnostnyy aspekt): monografiya [Functional system of verbal-communicative activity (competence aspect): monograph]. Izd-vo OOO "Shchedraya usadba plyus".

Karasik, V. I. (2000). O tipah diskursa [On discurse types]. Jazykovaja lichnost': institucional'nyj $i$ personal'nyj diskurs: Sb. nauch. tr. Peremena. 5-20.

Izyumtseva, G. (2020, January 12). Conceptual Metaphors in the Pentateuch Texts of English Bible (New King James Version). Scientific Journal of National Pedagogical Dragomanov University. Series 9. Current Trends in Language Development, 19, 47-73. https://doi.org/https://doi.org/10.31392/NPUnc.series9.2019.19.04

Kachanov, Ju. L. (2000). Teoreticheskie predposylki jempiricheskogo issledovanija sociologicheskoj teorii [Theoretical premises of sociological theory empirical investigation]. SOCIS, 3-10.

Kolesov, V. V. (2004) Jazyk $i$ mental'nost [Language and mentality]. SPb.: Peterburgskoe Vostokovedenie, 2004.

Kravtsova, Yu. V. (2013). Metaforicheskaya kontseptualizatsiya mira v khudozhestvennom tekste [Metaphorical conceptualization of the world in artistic text]. Naukovyi chasopys Natsionalnoho pedahohichnoho universytetu imeni M. P. Drahomanova. Seriia 9. Suchasni tendentsii rozvytku mov, 10. 149-159.

Kravtsova, Yu. V. (2014). Metaforicheskoe modelirovanie mira $v$ khudozhestvennom tekste: semantiko-kognitivnyy analiz: monografyja [Metaphorical modeling of the world in artistic text: semantic and cognitive analysis: monograph]. Izd-vo NPU im. M. P. Dragomanova.

Kravtsova, Yu. V. (2011). Semantyko-kohnityvne modeliuvannia metaforyzatsii [The semantic and cognitive modelling of metaphorization]. Movoznavstvo : nauk.-teor. Zhurn, 1.43-54.

Korolyova, A. V. (2011). Diakhronichnyi vektor doslidzhennia struktur svidomosti y myslennia [Diachronic vector of investigating the consciousness and cognition structures]. Visnyk KNLU. Seriia Filolohiia, 4 (1). 52-58.

Pocheptsov, O. G. (1990). Yazykovaya mentalnost: sposob predstavleniya mira [Language mentality: Mode of the universe presentation]. Voprosy yazykoznaniya, 6. 110-122.

Selivanova, O. O. (2008). Suchasna linghvistyka: naprjamy ta problemy : pidruchnyk [Modern linguistics: tendencies and problems: textbook]. Dovkillja-K.

Lakoff, G., \& Turner, M. (1989). More than Cool Reason: A Field Guide to a Poetic Metaphor. The University of Chicago Press. 
Lakoff, G. (1993). The contemporary theory of metaphor. Metaphor and thought [A. Ortony Ed.]. Cambridge University Press.

Lakoff, G., \& Johnson, M. (2003). Metaphors We Live by. Chicago: The University of Chicago Press.

Lakoff, G. (1990). Women, fire, and dangerous things. What categories reveal about the mind. The University of Chicago Press.

Lovejoy, A. O. (2001). The Great Chain of Being: A Study of the History of an Idea. Harvard University Press. Twenty-second reprinting.

Stienstra, N. (1993). YHVH is the Husband of His People: Analysis of a Biblical Metaphor with Special Reference to Translation. Kok Pharos Publishing House.

Wilber, K. (2000). One Taste: Daily Reflections on Integral Spirituality. SHAMBHALA.

\section{Sources of Illustrative Material:}

The Orthodox Study Bible (2008). The St. Athanasius Academy of Orthodox Theology. Thomas Nelson. Retrieved from: https://azbyka.ru/otechnik/books/original/18430/The_Orthodox_Study_Bible__St.pdf

\section{Бібліографічний опис:}

Ізюмцева, Г. В. (2020). Методика аналізу метафорики текстів П'ятикнижжя англомовної Бібілії. Науковий часопис Національного педагогічного університету імені М. П. Арагоманова. Серія 9. Сучасні тенденції розвитку мов, 20. 47-63. https://doi.org/10.31392/NPU-nc.series9.2020.20.04

\section{Анотація}

У статті розглядається актуальна проблема методології вивчення метафоричних смислів у біблійних текстах. Обгрунтовується необхідність виходу за рамки структурно-смислового аналізу текстів П'ятикнижжя за допомогою залучення нових методик для реконструкиії додаткових метафоричних смислів крізь призму доксичної пресупозичії й рефлективної реальності реципієнтів.

Визначаються вектори дослідження метафорики текстів П'ятикнижжя, а саме: 1) з позииій авторської докси (на базі текстів П'ятикнижжа); 2) з позиџій доксичної пресупозиұї реципієнтів (на базі опитувальних листків). Встановлюються ментально-вербальні виміри метафорики (метафорична картина світу, метафоричні конщепти; кончептуальні метафори), які й становлять методологію дослідження.

Описана комплексна методика аналізу метафорики включає: 1) прочедуру семантикокогнітивного метафоричного моделювання, спрямовану на реконстукию метафоричної картини світу (перший етап); 2) прочедуру реконструкції метафоричних концептів (другий етап); 3) прочедуру анкетування (третій етап); 4) процедуру семантико-когнітивної реконструкиї концептуальних метафор з позиџій доксичної пресуппозиџї (четвертий етап).

Аргументовано доиільність обраних методів і методичних прочедур; продемонстровано етапи аналізу метафоричного кончепту CHARACTER; встановлено його структуру; виявлено, що ядро біблійного метафоричного конщепту CHARACTER складас ознака 'mеrсу' (милосердя) (56\%), що домінуе над іншими конщептуальними ознаками, а відтак, є основною рисою характеру людини в ракурсі індивідуально-авторського світобачення.

Встановлено, що запропонована комплексна методика $\epsilon$ ефективною для дослідження метафорики текстів П'ятикнижжя.

Ключові слова: семантико-когнітивне моделювання, прочедура реконструкиії, метафора, доксична пресупозииія, метафоричний кониепт, конџептуальна метафора. 